\title{
A SWARA-COPRAS APPROACH TO THE ALLOCATION OF RISK IN WATER AND SEWERAGE PUBLIC-PRIVATE PARTNERSHIP PROJECTS IN MALAYSIA
}

\author{
Alireza VALIPOUR ${ }^{1}$, Nordin YAHAYA ${ }^{2, *}$, Norhazilan MD NOOR ${ }^{2}$, Iman VALIPOUR ${ }^{3}$, \\ Jolanta TAMOŠAITIENË ${ }^{4}$ \\ ${ }^{1}$ Department of Civil Engineering, Shiraz Branch, Islamic Azad University, Shiraz, Iran \\ ${ }^{2}$ Department of Structure and Materials, Faculty of Civil Engineering, Universiti Teknologi Malaysia, \\ Skudai, Johor, Malaysia \\ ${ }^{3}$ Department of Mechanical Engineering, Faculty of Mechanical Engineering, University of Tehran, Tehran, Iran \\ ${ }^{4}$ Institute of Sustainable Construction, Faculty of Civil Engineering, Vilnius Gediminas Technical University, \\ Sauletekio al. 11, 10223 Vilnius, Lithuania
}

Received 16 September 2016; accepted 11 February 2018

\begin{abstract}
In a situation of growing water demand, inadequate public funding, poor asset condition and lack of maintenance in developing countries, public-private partnerships (PPPs) play an important role in the development of infrastructure, such as water supply and sewerage services. The purpose of this study is to develop a quantitative approach to appropriate risk allocation, with attention directed to the impact of positive and negative factors in water and sewerage projects. The paper presents a hybrid SWARA-COPRAS approach to examine risk allocation, particularly for PPP water supply and sewerage projects in the context of Malaysia. In addition to PPP infrastructure projects, the approach has the potential to be adapted to other applications. The proposed method enables decision makers to utilise qualitative linguistic terms in the allocation of risk between the public and private sector, and to select the best strategy for risk allocation in a contract. Finally, 24 significant risks were identified: six risks would preferably be allocated to the public sector, while seven risks would be assigned to the private sector, and eleven risks would preferably be shared by both parties. The finding from this study can help the government of Malaysia to determine an attractive political strategy for private investors to support a PPP water and sewerage infrastructure project.
\end{abstract}

Keywords: water and sewerage projects, PPP, risk allocation, SWARA, COPRAS method.

\section{Introduction}

The provision of quality and efficient water and sewerage services is essential in ensuring rapid urbanisation and economic development. During the Tenth Malaysia Plan, 2011-2015, efforts were undertaken to improve water supply and sewerage services to ensure their sustainability (Economic Planning Unit, Prime Minister's Department, 2010). Water and sewerage infrastructure projects in Malaysia have become larger and thereby more complex and more innovative (FAO/ESCAP, 2001; Tan, 2012). This causes, among other things, a need for combined expertise and collaboration between public and private parties. This causes, among other things, a need for combined expertise and collaboration between public and private parties. Public-private partnerships allow for this collaboration to a large extent, mitigate the risk of local debt and increase financing capacity (Yang, Long, Cui, Zhu, \& Chen, 2017). Therefore, to boost economic growth through participation of the private sector, 16 water and sewerage PPP projects were initiated worth US $\$ 10.144$ million. According to the World Bank (2016), eight unsuccessful or failed water and sewerage PPP projects in Malaysia, such as the National Sewerage Project, the Kelantan Water Supply Project, the Indah Wastewater Urban Sewerage Rehabilitation and Sarawak Water Supply Project, were initiated at a cost of US $\$ 6.218$ million. Hence, a public-private partnership offers both advantages and disadvantages. For instance, PPPs provide essential public benefits in the form of assets or services. Conversely, the procurement process for PPP projects is longer and more expensive than traditional procurement processes. A public-private partnership therefore involves risks for the private sector

*Corresponding author. E-mail: nordiny@utm.my 
organisation, which expects compensation for accepting those risks, which can increase government costs.

Due to their complexity and unique characteristics, water supply and sewerage projects carry inherent risks. Following Ameyaw and Chan (2016), the PPP model proposes to find ways to resolve these risks and allocate them between the public and private sector. Therefore, risk management is essential for PPP water supply and sewerage projects. Appropriate risk allocation and shared targets are essential to the success of PPP projects (Osei-Kyei \& Chan, 2015; Grasso \& Soldo, 2017). Hence, a focus on collaboration is required for appropriate risk allocation, rather than merely allocating all risks to one party without an assessment of a party's ability to bear and control the risk.

In general, the goal of the private sector is to profit from its capacity and experience in managing businesses, while the primary objective of the public sector is to meet public needs effectively and efficiently. These different interests lead to disagreements over risk allocation preferences between public and private sector parties. The allocation of risk should be carried out optimally; otherwise, the actual value of the money target will probably be threatened. Imperfect risk allocation comprises one of the main causes of the failure of private sector participation (Marques \& Berg, 2011). Improper risk allocation has negative impacts on the success of a PPP project in terms of time, cost and quality (Ke, Wang, \& Chan, 2013; Jae-Seung \& Yea-Sang, 2017). Equitable risk allocation depends on many criteria and barriers, such as the ability to manage risk and the attitude of stakeholders towards shared responsibility (Iqbal, Choudhry, Holschemacher, Ali, \& Tamošaitienè, 2015; Zhang, Ding, Wu, \& Skibniewski, 2017). There are several barriers associated with risk allocation in the PPP projects, such as cooperation, negotiation, teamwork, collaboration, trust and communication. Therefore, it is necessary to broadly consider the criteria and barriers of risk allocation to achieve appropriate risk allocation (Valipour, Mohammadi, Yahaya, Sarvari, \& Noor, 2014; Grasso \& Soldo, 2017). It is also essential for public and private sector parties to apply efficient risk allocation approaches in PPP projects to experience a more effective process of agreement arbitration and to reduce the occurrence of disputes during the concession period (Alireza, Mohammadreza, Zin, Yahaya, \& Noor, 2013).

Earlier research studies on public-private partnerships indicate that equitable risk allocation among different parties is crucial to the successful implementation of PPP projects. However, current studies in this research area related to water supply and sewerage PPP projects in Malaysia are limited. The lack of research within a Malaysian context reinforces the significance of this study. This research is thus essential and timely to further enrich the knowledge base on water supply and sewerage PPP projects in Malaysia. Little is known about how to determine the party responsible for ensuring optimal risk management considering the criteria and the barriers of risk allocation. It is vital for the private and public sector to understand the various risks related to water supply and sewerage PPPs through the entire life cycle of infrastructure projects, the significance of risks, and the best way to allocate risks to ensure the long-term success of such partnerships. The identification, classification, evaluation and investigation of problems with this particular current practice of the allocation of risk and the evaluation of positive and negative factors to optimal risk allocation in the water supply and sewerage PPP project can represent an authentic contribution to the body of knowledge and to PPP projects. The aim of this study is to represent and propagate a decision model based on efficiency and capability in handling uncertainty.

To realise this goal, the hybrid SWARA-COPRAS approach is used to provide an accurate range of the uncertainty, simulating the ambiguity of expert judgment and the simultaneous consideration of the impact of positive and negative factors in fair risk allocation. An in-depth understanding of risk allocation is essential to the PPP agreement. The model developed in this study represents a significant contribution to the original body of information on water and sewerage PPP projects, as well as construction projects. The proposed model can be used as a reliable and practical risk management model for fair risk allocation in PPP projects. The findings from the research may also help the public and private sector in the development of a framework that can be used for bidding to predict and respond to risks in water and sewerage projects in Malaysia. Even though a rather large body of literature has been published on PPPs, there is a lack of both experience and published studies related to risk allocation in water and sewerage PPP projects in Malaysia. The results of this study provide insights into the development and performance improvement of water supply and sewerage PPP projects, especially in Malaysia.

\section{Literature review}

Many researchers have studied risks in PPP water supply and sewerage projects from various perspectives. Chan, Lam, Wen, Ameyaw, Wang, and Ke (2015) identified and evaluated typical risks associated with PPP projects in the Chinese water supply sector. Sixteen critical risk factors (CRFs) were identified through a comprehensive literature review, a Delphi survey and face-to-face interviews. The findings revealed that completion risk, inflation and price change risk have a higher impact on Chinese water PPP projects; whereas government corruption, an imperfect legal and supervisory system, and changes in market demand have a lower impact on the water supply sector. Xu, Chan, and Yeung (2010) developed a risk allocation model for PPP projects in China. Twenty-three risk factors were identified through a comprehensive literature review. The most critical nine risk allocation criteria were identified, validated and compiled based on expert knowledge via face-to-face interviews. Tan (2012) argued that problems were related to political rent seeking and weak (and highly politicised) regulation and identified overstated investments by the 
private sector as the most important risks in Malaysia's PPP water and sewerage projects. Yang et al. (2017) analysed types of risk and problems that affect the implementation of the PPP model in urban sewage treatment projects in China. Wibowo and Mohamed (2010) analysed risk criticality and allocation in the context of PPP water supply development projects in Indonesia. They reported that variables such as the non-availability of raw water, the entry of new competitors, construction cost escalation, tariff-setting uncertainty and breach of contract by the government are the most critical risks among 39 risk factors identified. Ameyaw and Chan (2015) provided a list of 22 critical risk factors that have a strong impact on PPP water projects in Ghana. The top-ranked risks include the foreign exchange rate, corruption, water theft, non-payment of bills and political interference. Choi, Chung, and Lee (2010) found that the revocation of a fixed return policy, the current low level of water prices and the difficulty of adjustment are the most significant risks that cause foreign companies to retreat from China's water PPP market. According to Zeng, Wan, Tam, and Liu (2007), top-ranked risks in China's build-operate-transfer (BOT) water projects include tax policy change, interest rate fluctuation, raw water price instability, foreign exchange rates and competitors. Thus, it is important to determine the most significant risks for PPP projects. However, there is no universal set of risk factors applicable to all PPP projects and agreed upon as the most prevalent. Such risks differ across different projects, sectors and countries.

Risk allocation in PPP projects is not a new issue. Previous studies in this area can be divided into three types of research approaches. The quantitative methods were first developed for risk allocation. Chang (2014) investigated the optimal risk-sharing ratio between owners and contractors. An integrated fuzzy system dynamics approach was provided for risk allocation. Ameyaw and Chan (2016) proposed a quantitative fuzzy approach for risk allocation in water-infrastructure projects in Ghana. Alireza et al. (2013) used a hybrid AHP and genetic algorithm for allocation of risk in Malaysian PPP projects. G. Khazaeni, M. Khanzadi, and Afshar (2012a) proposed a fuzzy AHP approach to provide a method of balancing risk allocation in construction projects. Jin and Zhang (2011) applied artificial neural network (ANN) models to model the risk allocation decision-making process in PPP projects, primarily drawing upon transaction cost economics. In summary, a variety of methods has been employed for risk allocation. The second set of approaches focuses on the principles of risk allocation. Several studies (Lam, Wang, Lee, \& Tsang, 2007; Jin \& Doloi 2008; Xu et al., 2010; Khazaeni et al., 2012a, 2012b; Ameyaw \& Chan, 2016) have suggested criteria and principles for equitable risk allocation. All of these risk allocation principles commonly use natural language and the qualitative judgment of experts. The qualitative methods represent the third approach to risk allocation based on the question- naire survey. El-Sayegh (2008) identified significant risks in the United Arab Emirates (UAE) construction industry and addressed their proper allocation to the appropriate contracting party. A questionnaire was used to obtain the perceptions of construction experts. Loosemore and McCarthy (2008) studied risk allocation in construction and supply chains using a questionnaire survey. The survey indicated that the key to better managing perceptions of risk is fundamentally one of communication, consultation and involvement in contractual decision-making. Jin and Doloi (2008) proposed a theoretical framework for risk allocation in PPP projects. This framework was tested using an industry-wide survey. Carbonara, Costantino, Gunnigan, and Pellegrino (2015) defined the most significant risks in PPP motorway projects and identified both effective allocation and suitable mitigation strategies. Hwang, Zhao, and Yu (2016) identified the critical risks faced by parties that perform underground rail construction projects as part of international construction joint ventures. Although the survey respondents recognised that the allocation of risk between major parties is crucial, obstacles to risk allocation still exist. From the perspective of foreign contractors, differences in culture and working styles had the most negative influence on appropriate risk allocation, while local firms regarded the unclear division of responsibilities and risks as the major obstacle. Bing, Akintoye, Edwards, and Hardcastle (2005) explored risk allocation in PPP construction projects in the UK. The research findings showed that the public sector partner should retain site availability and political risks. Both parties should share relationship risks, force majeure risks and the risks of legislative changes. However, the majority of the remaining project risks, especially those at the meso risk level, should be allocated to the private sector partner. Hwang, Zhao, and Gay (2013) studied perceptions of risk allocation in PPP projects in Singapore and identified 11 risks that public and private sector partners preferred to share.

A review of previous studies revealed that researchers strove to find appropriate risk allocation patterns for construction projects, but very few publications were written specifically to address risk allocation in PPP projects in the water and sewerage sector - especially in Malaysia. One of the weak aspects of common models for risk allocation in PPP infrastructure projects is a lack of attention to the impact of criteria (positive factors) and barriers (negative factors). The influence from criteria and barriers can lead to a significant variation in decision outcomes regarding risk allocation based on attitude, acceptability and manageability of the risk between public and private sectors. This paper strives to fill these gaps by developing a hybrid SWARA-COPRAS approach. The main objective of the study to deploy the best risk allocation experience and practice of the PPP water supply and sewerage projects in Malaysia, and to provide the industry with the approach that can be used for the proper allocation of risks to the party best able to manage them. 


\section{Research framework}

The primary stages of the research framework are illustrated in Figure 1. Each stage is described in greater depth in the following sections.

Stage 1: to identify significant risks in PPP water supply and sewerage projects in Malaysia. This stage includes a comprehensive literature review and interviews with experts to identify all types of risk in these projects. A risk matrix is used to identify significant risks.

Stage 2: to identify and determine the importance of risk allocation criteria and barriers. This stage includes a comprehensive literature review and interviews with experts to identify all types of criteria and barriers. The weights of the criteria and barriers are determined using the SWARA method.

Stage 3: to develop a hybrid SWARA-COPRAS evaluation model to determine equitable risk allocation between the public and private sector considering the criteria and barriers. This section includes the survey design and analysis of the results using the COPRAS method.

To enhance the representativeness of the sample, participants associated with the public and private sector in water and sewerage PPP projects were surveyed. The participants for the survey were drawn from the Construction Industry Development Board (CIDB), the Real Estate and Housing Developers' Association Malaysia (REHDA), the Public Private Partnership Unit (known as UKAS), and an international company working on water supply and sewerage PPP projects in Malaysia. The expert panel included a project manager/estimator, the primary contractor, a quantity surveying manager, a sub-contractor, and the technical director of the Malaysian PPP project. Finally, 110 respondents were identified who could answer the questionnaires for this research project. The types of respondents' roles for this study were categorised into two

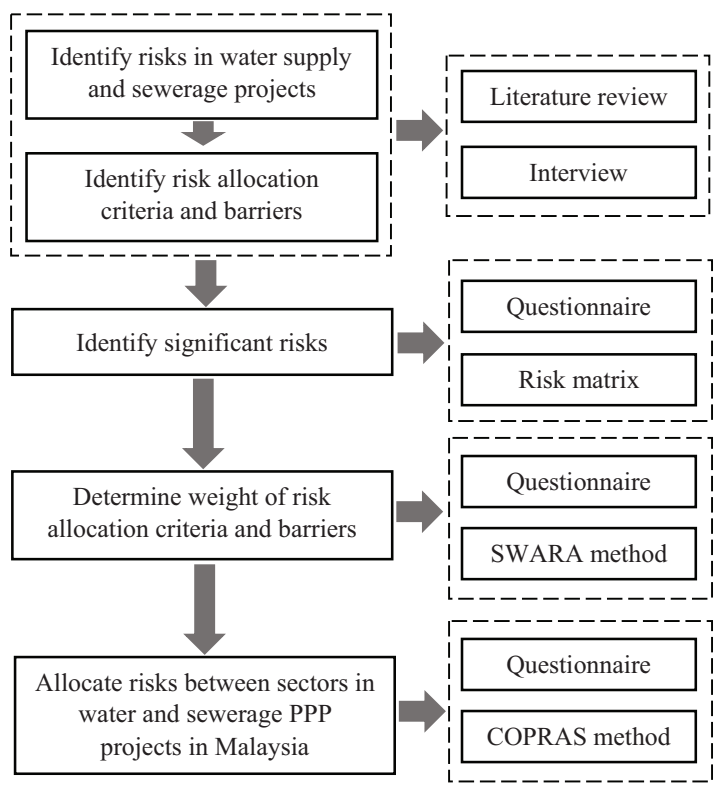

Figure 1. Research method schematic groups: public and private roles. There were 62 respondents working in private sector roles and 48 respondents working in public sector roles. Overall, the results demonstrate that the majority of the respondents were working in private roles. All respondents had experience in water and sewerage PPP projects. Sixty-five respondents had experience in risk management of PPP projects.

\subsection{Questionnaire}

The questionnaire survey was conducted as a secondary resource to collect data for this research. Three types of questionnaires were used in this research. Questionnaire type A was designed to obtain the rank of each risk based on impact and frequency. The first section provided general information regarding the respondents, such as years of experience in PPP projects, especially water supply and sewerage projects, type of project involved, type of role in the project and background information about the individual completing the questionnaire. These questions were designed to identify the background of the respondents and to certify their responses. The second part included the primary questions about the weight of each risk assessment. The risk factors were rated on a 5 -point Likert scale according to frequency ( $1=$ Very low frequency, 2 = Low frequency, 3 = Moderate frequency, 4 = High frequency, 5 = Very high frequency) and impact $(1=$ Insignificant, $2=$ Minor, $3=$ Moderate, $4=$ Major, 5 = Severe).

The type B questionnaire included two sections. The first section asked for the same general information from respondents as the same section in questionnaire type A. The second part included the primary questions regarding the evaluation of each risk allocation's criteria and barriers. To measure the importance of each risk allocation's criteria and barriers, respondents were required to separately indicate the level of each risk allocation's criteria and barriers. The 5 - point Likert scale ( $1=$ Equal importance, 2 = Moderate importance, $3=$ Strong importance, 4 = Very strong importance, $5=$ Extreme importance) was used for this section. The weight of each risk allocation's criteria and barriers were obtained by SWARA method.

The type C questionnaire was designed for the SWARA-COPRAS method. This type of questionnaire focused on respondents' perceptions regarding the allocation of PPP risks. In other words, respondents were asked to allocate the risk based on criteria and barriers, whether under public, private or shared obligations. The researchers asked respondents to determine the optimal risk allocation between partners or as a shared risk in a PPP project in a simple questionnaire. The 5 - point Likert scale was used for this part same, as was the case for type B.

\subsection{Risk analysis matrix}

To identify the significant risks in Malaysian water and sewerage PPP projects, the respondents were required to reveal the level of frequency of the risk event and the 
amount of risk impact. The risk scores are determined by multiplying the mean of frequency and the mean of the impact of risk as follows (Alireza et al., 2013).

$$
\text { Riskscore }=F_{r} \times I_{r} \text {, }
$$

where: $F_{r}$ is the mean of frequency of risk occurrence and $I_{r}$ is the mean of the impact of risk. Table 1 shows the rating of the risk analysis matrix. Consequently, a list of the major risks in Malaysian PPPs is the core objective of this step.

The risk priority is based on the following ranges (DOSH, 2008):

- Score 15-25: A HIGH risk requires immediate action to control the hazard, as detailed in the hierarchy of control. Actions taken must be documented on the risk assessment form, including date of completion.

- Score 5-14: A MEDIUM risk requires a planned approach to control the hazard and apply temporary measures if required. Actions taken must be documented on the risk assessment form, including date of completion.

- Score 1-4: A risk identified as LOW may be considered acceptable, and further reductions may not be necessary. However, if the risk can be resolved quickly and efficiently, control measures should be implemented and recorded.

\subsection{Step-wise weight assessment ratio analysis (SWARA) method}

In this paper, the step-wise weight assessment ratio analysis (SWARA) method was used to obtain the weight of risk allocation criteria and barriers. Using SWARA, the criteria are ranked by experts in terms of their importance, i.e., the most significant criterion is given rank 1 , and the least significant criterion is given the last rank. The overall ranks for the group of experts are determined according to the median value of the ranks. The SWARA method for the criteria weights determination can be described as follows:

1. Sorting the evaluation criteria in descending order based on their expected importance;

2. Evaluation of the degree to which the $C_{j}$ criterion is more important than the $\mathrm{C}_{\mathrm{j}+1}$ criterion $\left(s_{j}\right)$;

3. Determination of coefficient $k_{j}$;
4. Determination of recalculated weight $w_{j}$;

5. Determination of weight $q_{j}$.

The procedure for the criteria weight determination is presented in Figure 2.

For a comprehensive overview of the SWARA methodology, the reader is referred to Keršuliene, Zavadskas, and Turskis (2010) and Karabašević, Stanujkić, Urošević, and Maksimović (2016). Several researchers (Aghdaie, Zolfani, \& Zavadskas, 2013; Zolfani \& Saparauskas 2013; Zolfani \& Bahrami 2014) have attempted to use the SWARA method to solve different problems. However, the SWARA method has not been applied to determine the most significant criteria for risk allocation in PPP projects.

\subsection{COPRAS method}

The COmplex PRoportional ASsessment (COPRAS) method was first introduced by Zavadskas and Kaklauskas (1996). This method can be used in situations where decision makers have to choose between alternatives with respect to a particular set of inconsistent criteria. COPRAS has the ability to account for both positive (maximising) and negative (minimising) evaluation criteria.

The COPRAS method determines a solution with the ratio to the best solution. This method assumes direct and proportional dependence of significance and priority of investigated alternatives for a set of evaluation criteria, criteria weights and values. Since COPRAS has been widely discussed in the literature, we prefer to discuss only the results here. For a comprehensive overview of the COPRAS method, the reader is referred to Kaklauskas, Zavadskas, Raslanas, Ginevicius, Komka, and Malinauskas (2006) and Zavadskas, Kaklauskas, Turskis, and Tamošaitiene (2008).

Several researchers (Zavadskas, Kaklauskas, Peldschus, \& Turskis, 2007; Zavadskas, Turskis, \& Tamosaitiene 2010; Kundakcı \& Işıı, 2016; Mulliner, Malys, \& Maliene, 2016; Organ \& Yalçın, 2016) have attempted to use the COPRAS method for different decision making situations.

\section{Data analysis and discussion}

\subsection{Reliability analysis for study}

A pilot questionnaire was conducted prior to the distribution of questionnaires to test the feasibility of intended questionnaires to be undertaken and to perfect the

Table 1. Risk matrix (Department of Occupational Safety and Health [DOSH], 2008)

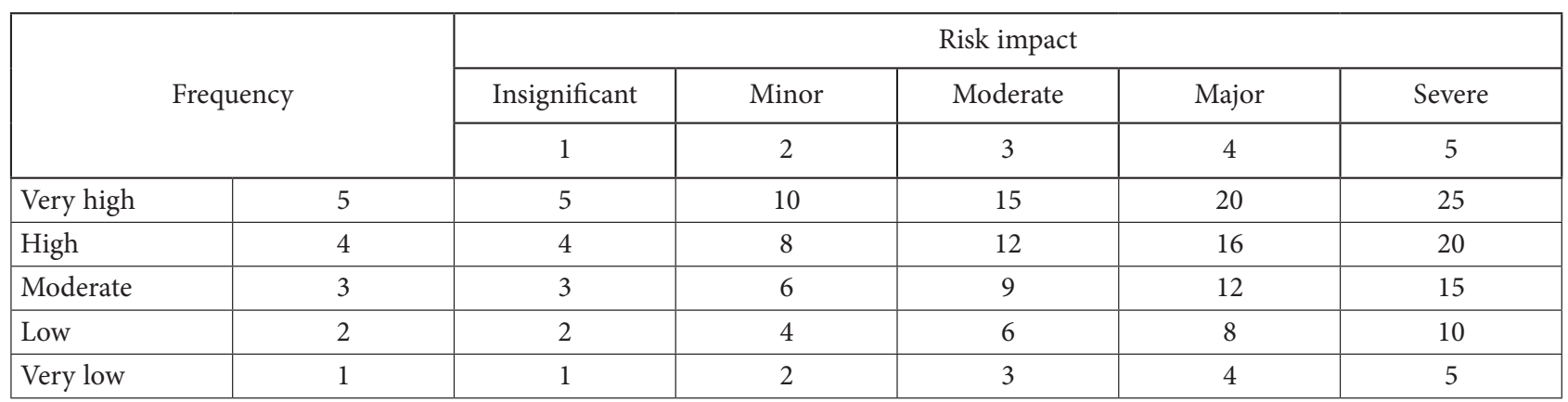




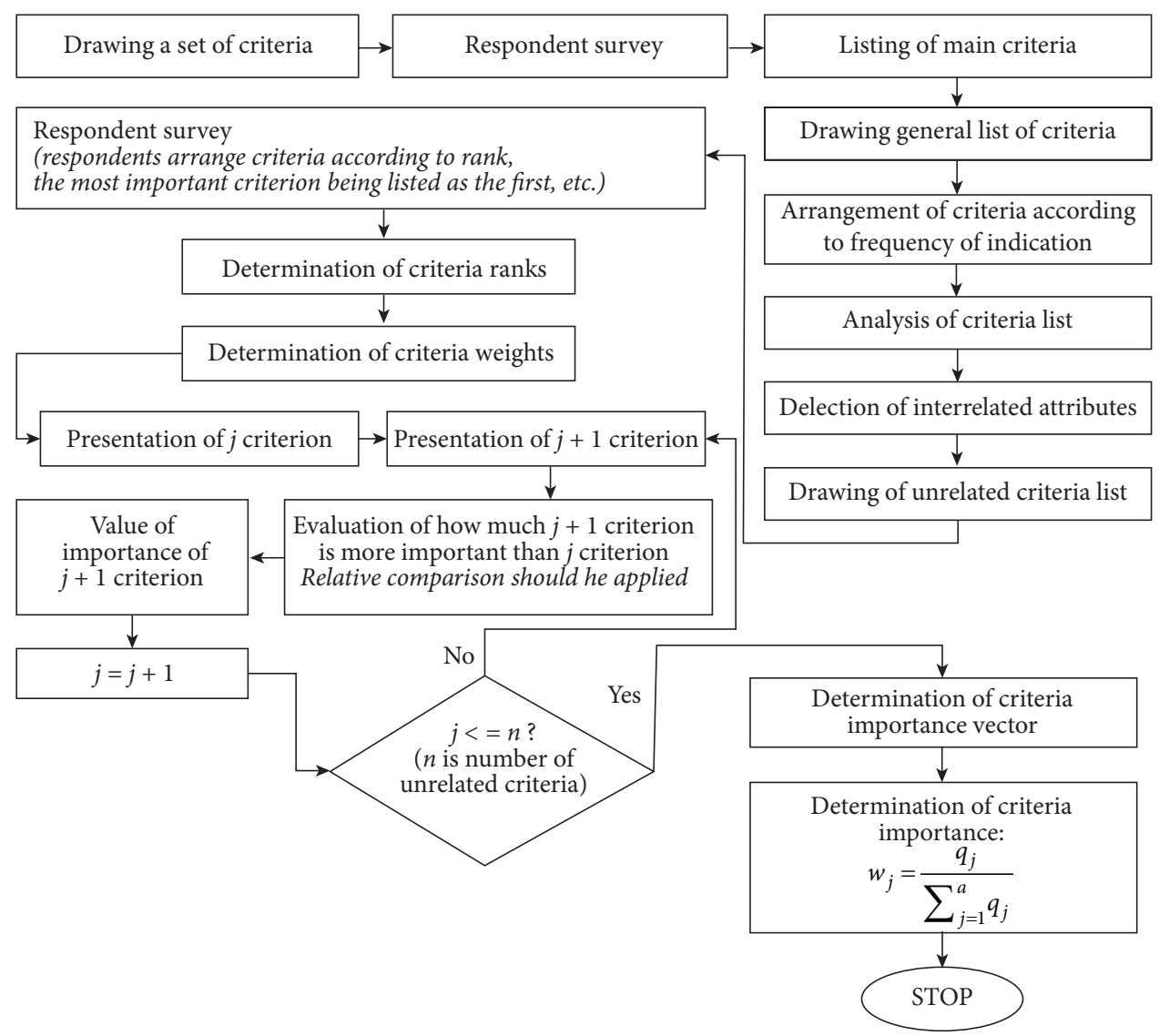

Figure 2. Determining of the criteria weights based on SWARA

questionnaire concepts and wording. Participants in the pilot study involved 20 experts who have experience with PPP projects within Malaysia.

In this study, the reliability test was performed for each type of questionnaire. Cronbach's alpha was used as the measure of internal consistency. In all three questionnaires, the reliability appears to be excellent $(\alpha>0.9)$ (Bhatnagar, Kim, \& Many 2014), with Cronbach's alpha above 0.7 (see Table 2).

Table 2. Cronbach's alpha value for questionnaire

\begin{tabular}{|c|c|}
\hline Type of questionnaire & Cronbach's alpha value \\
\hline Type A & 0.946 \\
\hline Type B & 0.924 \\
\hline Type C & 0.936 \\
\hline
\end{tabular}

\subsection{Questionnaire return rate}

A total of 110 questionnaires were distributed, with 45 sets distributed by e-mail and 65 questionnaires handed directly to the participants. In total, 105 questionnaires were returned (see Table 3 ), representing a response rate of $95.45 \%$. Of the 105 returned questionnaires, only 93 $(84.54 \%)$ were deemed adequate for the research purposes.
Table 3. Sample characteristics

\begin{tabular}{|l|c|c|}
\hline & Quantity & Percentage, \% \\
\hline Questionnaire distributed & 110 & 100 \\
\hline $\begin{array}{l}\text { Questionnaire returned } \\
\text { and valid }\end{array}$ & 93 & 84.55 \\
\hline $\begin{array}{l}\text { Questionnaire returned } \\
\text { but invalid }\end{array}$ & 12 & 10.9 \\
\hline Missing & 5 & 4.55 \\
\hline
\end{tabular}

Table 4 shows the background information of the respondents: $82.8 \%$ came from the construction industry, and $17.2 \%$ came from the academic sector. Furthermore, nearly $60.2 \%$ of the respondents had more than 10 years of experience.

\subsection{Significant risks in Malaysian PPP sewerage and water supply projects}

Preliminary data was collected through a literature review of papers related to risk identification, risk assessment and risk allocation in water and sewerage PPP projects. The risk factors were generated based on an extensive literature review, with an emphasis on the works of Zeng et al. (2007), Choi et al. (2010), Wibowo and Mohamed (2010), Tan (2012), Ameyaw and Chan (2013), Ameyaw and Chan (2015), Valipour et al. (2015) and Ameyaw and 
Table 4. Background characteristics of the respondents

\begin{tabular}{|c|c|c|c|c|c|c|c|}
\hline \multicolumn{8}{|c|}{ Role } \\
\hline \multicolumn{2}{|l|}{ Sector } & \multicolumn{3}{|c|}{ Construction/industrial } & \multicolumn{3}{|c|}{ Academic } \\
\hline \multicolumn{2}{|l|}{ Number } & \multicolumn{3}{|c|}{77} & \multicolumn{3}{|c|}{16} \\
\hline \multicolumn{2}{|l|}{ Percentage, \% } & \multicolumn{2}{|c|}{82.8} & & \multicolumn{2}{|c|}{17.2} & \\
\hline \multicolumn{8}{|c|}{ Position } \\
\hline Category & $\begin{array}{l}\text { Project } \\
\text { manager }\end{array}$ & $\begin{array}{l}\text { Quality } \\
\text { manager }\end{array}$ & Investor & $\begin{array}{c}\text { Sub- } \\
\text { contractor }\end{array}$ & $\begin{array}{l}\text { Deputy } \\
\text { director }\end{array}$ & $\begin{array}{l}\text { Technical } \\
\text { director }\end{array}$ & Academic \\
\hline Number & 15 & 12 & 16 & 14 & 12 & 8 & 16 \\
\hline Percentage, \% & 16.1 & 12.9 & 17.2 & 15.1 & 12.9 & 8.6 & 17.2 \\
\hline \multicolumn{8}{|c|}{ Industrial experience } \\
\hline \multicolumn{2}{|l|}{ Years } & \multicolumn{2}{|l|}{$5-10$} & $11-15$ & & \multicolumn{2}{|c|}{$\geq 16$} \\
\hline \multicolumn{2}{|l|}{ Number } & \multicolumn{2}{|l|}{37} & 47 & & \multicolumn{2}{|c|}{9} \\
\hline \multicolumn{2}{|l|}{ Percentage, \% } & \multicolumn{2}{|l|}{39.8} & 50.5 & & \multicolumn{2}{|c|}{9.7} \\
\hline
\end{tabular}

Table 5. Significant risks in water and sewerage PPP projects in Malaysia

\begin{tabular}{|c|c|c|c|c|c|}
\hline Risks group & Risk factor & $\begin{array}{l}\text { Frequency } \\
\quad F_{r}\end{array}$ & $\underset{I m p a c t}{I_{r}}$ & $\begin{array}{l}\text { Risk score } \\
\quad F_{r} \times I_{r}\end{array}$ & $\begin{array}{l}\text { Rank of } \\
\text { each risk }\end{array}$ \\
\hline $\mathrm{R}_{1}$ : Operational risks & $\begin{array}{l}\mathrm{R}_{11}: \text { High operational cost } \\
\mathrm{R}_{12}: \text { Equipment defect and lack of maintenance } \\
\mathrm{R}_{13}: \text { Poor performance } \\
\mathrm{R}_{14}: \text { Water theft }\end{array}$ & $\begin{array}{l}3.7 \\
4.1 \\
4.4 \\
4.4\end{array}$ & $\begin{array}{l}3.9 \\
3.9 \\
3.6 \\
4.1\end{array}$ & $\begin{array}{l}14.43 \\
15.99 \\
15.84 \\
17.22\end{array}$ & $\begin{array}{c}19 \\
9 \\
11 \\
3\end{array}$ \\
\hline $\begin{array}{l}\mathrm{R}_{2}: \text { Political and } \\
\text { regulatory risks }\end{array}$ & $\begin{array}{l}\mathrm{R}_{21}: \text { Political interference } \\
\mathrm{R}_{22}: \text { Termination of contract by government } \\
\mathrm{R}_{23}: \text { Government's commitment risk } \\
\mathrm{R}_{24}: \text { Political corruption } \\
\mathrm{R}_{25}: \text { Weak regulatory and monitoring regime }\end{array}$ & $\begin{array}{l}4.4 \\
4 \\
3.8 \\
4.3 \\
3.7 \\
\end{array}$ & $\begin{array}{c}4.2 \\
4.1 \\
4 \\
4.2 \\
3.8\end{array}$ & $\begin{array}{c}18.48 \\
16.4 \\
15.52 \\
18.06 \\
14.06\end{array}$ & $\begin{array}{c}1 \\
7 \\
15 \\
2 \\
23\end{array}$ \\
\hline $\mathrm{R}_{3}$ : Financial risks & $\begin{array}{l}\mathrm{R}_{31}: \text { Financial availability } \\
\mathrm{R}_{32}: \text { Unfavourable global private investment climate } \\
\mathrm{R}_{33}: \text { Foreign exchange rate }\end{array}$ & $\begin{array}{c}4.1 \\
4 \\
4\end{array}$ & $\begin{array}{l}3.5 \\
3.3 \\
4.3\end{array}$ & $\begin{array}{c}14.35 \\
13.2 \\
17.2\end{array}$ & $\begin{array}{c}21 \\
24 \\
4\end{array}$ \\
\hline $\begin{array}{l}\mathrm{R}_{4}: \text { Market/revenue } \\
\text { risks }\end{array}$ & $\begin{array}{l}\mathrm{R}_{41}: \text { Delayed and non-payment of bills } \\
\mathrm{R}_{42}: \text { Uncertain tariff reviews }\end{array}$ & $\begin{array}{c}4 \\
3.1 \\
\end{array}$ & $\begin{array}{l}4.2 \\
4.1\end{array}$ & $\begin{array}{c}16.8 \\
12.71\end{array}$ & $\begin{array}{c}5 \\
21 \\
\end{array}$ \\
\hline $\mathrm{R}_{5}:$ Relationship risks & $\begin{array}{l}\mathrm{R}_{51}: \text { Strained relationships } \\
\mathrm{R}_{52}: \text { Poor commitment from private party } \\
\mathrm{R}_{53}: \text { No risk allocation mechanism } \\
\mathrm{R}_{54}: \text { Weak capacity of public and private partners } \\
\mathrm{R}_{55}: \text { Inexperience in PPPs }\end{array}$ & $\begin{array}{c}3.7 \\
3.84 \\
4.2 \\
3.7 \\
4.7 \\
\end{array}$ & $\begin{array}{c}4 \\
4.1 \\
3.7 \\
4.1 \\
3.5 \\
\end{array}$ & $\begin{array}{l}14.76 \\
15.74 \\
15.54 \\
15.17 \\
16.45 \\
\end{array}$ & $\begin{array}{c}18 \\
12 \\
14 \\
16 \\
6\end{array}$ \\
\hline $\mathrm{R}_{6}$ : Social risks & $\begin{array}{l}\mathrm{R}_{61}: \text { Public opposition } \\
\mathrm{R}_{62}: \text { Delayed process } \\
\mathrm{R}_{63}: \text { No-pro-poor measures }\end{array}$ & $\begin{array}{c}3.8 \\
4.3 \\
4\end{array}$ & $\begin{array}{l}4.1 \\
3.7 \\
3.6 \\
\end{array}$ & $\begin{array}{l}15.58 \\
15.91 \\
14.41 \\
\end{array}$ & $\begin{array}{l}13 \\
10 \\
20\end{array}$ \\
\hline $\mathrm{R}_{7}:$ Force majeure & $\begin{array}{l}\mathrm{R}_{71}: \text { Severe weather } \\
\mathrm{R}_{72}: \text { natural disasters }\end{array}$ & $\begin{array}{l}3.7 \\
3.9\end{array}$ & $\begin{array}{c}4 \\
4.2\end{array}$ & $\begin{array}{c}14.8 \\
16.38\end{array}$ & $\begin{array}{c}17 \\
8\end{array}$ \\
\hline
\end{tabular}

Chan (2016). Interviews with experts were conducted as secondary resources to achieve the results of this section. Experts were asked to identify significant risks for water and sewerage PPP projects in Malaysia based on risks identified from the literature review. As a result, 43 risk factors in water and sewerage PPP projects were successfully identified. In order to achieve the first objective of the paper, the experts were required to indicate the level of frequency of risk occurrence and the level of impact of risk. Mean analysis was used to find the mean of frequency and the impact of risk. As shown in Table 1, the risk score can be calculated by multiplying the mean of frequency and the mean of the impact of risk. As a result, 24 significant risk factors (i.e., a risk score above 14) in six group (see Table 5) were successfully identified in Malaysian water supply and sewerage PPP projects.

Referring to Table 6, political interference risk $\left(R_{21}\right)$ was the most critical risk factor, which ranked first with a score of 18.44. Political interference risk affects PPPs in all aspects, but water is unique given its public health, social, political and environmental repercussions (Ameyaw \& Chan, 2015). Political interference has been identified 
Table 6. The weight of risk allocation criteria

\begin{tabular}{|l|c|c|c|c|}
\hline \multicolumn{1}{|c|}{ Criteria (+) } & $\begin{array}{c}\text { Comparative } \\
\text { importance of } \\
\text { average value } \\
s_{j}\end{array}$ & $\begin{array}{c}\text { Coefficient } \\
k_{j}=s_{j}+1\end{array}$ & $\begin{array}{c}\text { Recalculated weight } \\
w_{j}=\frac{w_{j-1}}{k_{j}}\end{array}$ & $q_{j}=\frac{w_{j}}{\sum_{j=1}^{n} w_{j}}$ \\
\hline $\mathrm{C}_{1}:$ Bear the risk at the lowest price & - & 1 & 1 & 0.1671 \\
\hline $\mathrm{C}_{2}:$ Foreseeing risk & 0.21 & 1.21 & 0.8264 & 0.1381 \\
\hline $\mathrm{C}_{3}:$ Control the chance of risk & 0.160 & 1.16 & 0.6271 & 0.1191 \\
\hline $\mathrm{C}_{4}:$ Risk attitude & 0.136 & 1.108 & 0.5660 & 0.0946 \\
\hline $\mathrm{C}_{5}:$ Resources of risk control & 0.108 & 1.09 & 0.5192 & 0.0868 \\
\hline $\mathrm{C}_{6}:$ Capability of control risk & 0.09 & 1.082 & 0.4799 & 0.0802 \\
\hline $\mathrm{C}_{7}:$ Direct assumption of risk & 0.082 & 1.079 & 0.4447 & 0.0743 \\
\hline $\mathrm{C}_{8}:$ Obtain intangible asset & 0.079 & 1.072 & 0.4149 & 0.0693 \\
\hline $\mathrm{C}_{9}:$ Minimize loss if risk occurs & 0.072 & 1.063 & $\sum_{j=1}^{n} w_{j}=5.9809$ & 0.3903 \\
\hline $\mathrm{C}_{10}:$ Sustain the consequence & 0.063 & & \\
\hline & & & & 0.0652 \\
\hline
\end{tabular}

$S_{j}$ is calculated based on the average of the expert's judgement. The information was gained individually from each expert. The importance of each criterion is calculated based on the relative importance of higher criterion. For example, 0.21 shows the relative difference of $C_{2}$ and $C_{1}$. For other criteria, the processes are the same.

as a major failure factor in water and sewerage PPP projects and adversely affects the efficiency of water provision (Kauffmann \& Pérard, 2007). It is apparent and important in tariff setting and the adjustment of top management (including the managing director). Economic tariffs are prerequisites to the sustainment of water supply systems. Tariff setting and approval have historically been the domain of the sector ministers prior to the creation of an "independent" economic regulator, which has not significantly addressed the problem.

Political corruption risk $\left(\mathrm{R}_{24}\right)$ was the second-most significant water PPP project risk, with a score of 18.06. Water and sewerage projects are very prone to corruption risk, including bid shopping, payment games, falsified claims, overbilling and unbalanced bids (Hall \& Lobina, 2007). Corruption has the consequence of eroding anticipated gains from PPPs while transferring costs to consumers in the form of increased tariffs and low-quality service. The long-term nature of water contracts serves to increase the incentive for corruption (Hall \& Lobina, 2007). Corruption risk in public procurement is attributable to a lack of commitment of political leadership to combat corrupt practices (Abdulai, 2009).

Water theft $\left(\mathrm{R}_{14}\right)$ was the risk ranked third, with score of 17.22. In the urban water sector, water theft is prevalent. This risk can affect the commercial operations of a service provider. Private operators in Malaysia will continue to battle water theft without yielding desired results.

Foreign exchange risk $\left(R_{33}\right)$ was ranked fourth, with a score of 17.2. The local currency of Malaysia (RM) has experienced substantial depreciation against the major trading currencies (US dollar, Euro) since 2010. Foreign exchange rate exposure has a negative impact on financial and budgetary implementation of PPP projects in Malaysia. Foreign exchange rates can also impact the private sector investment of water and sewerage projects because of lengthy payback periods, financing needs, and pricing and tariff adjustment difficulties. Non-payment of bills $\left(\mathrm{R}_{41}\right)$ was the fifth-most significant risk in the Malaysian water PPP project, with a score of 16.8 .

\subsection{Evaluation of risk allocation barriers and criteria}

Identification and evaluation of risk allocation criteria and barriers is needed to achieve optimal risk allocation for PPP projects (Valipour et al., 2014). Criteria and barriers to optimal risk allocation have to be determined before the risk is allocated, and all parties involved must anticipate the risk in order to be more organized and prepared. Criteria and barriers to optimal risk allocation must be determined before the risk is allocated, and all parties involved must anticipate the risk in order to be more organised and prepared. Preliminary data was collected through a literature review of papers related to risk allocation and management in PPP projects and construction projects (Jin \& Doloi, 2008; Xu et al., 2010; Khazaeni et al., 2012a, 2012b; Ameyaw \& Chan, 2016). The interviews were conducted as secondary resources to determine the risk allocation criteria and barriers associated with Malaysian PPP water and sewerage projects.

In the next step, SWARA was applied to obtain the weight of each barrier and each criterion. Therefore, the questionnaire design was based on the SWARA method and was distributed by email to experts in identified PPP 
Table 7. The weight of risk allocation barriers

\begin{tabular}{|c|c|c|c|c|}
\hline Barriers (-) & $\begin{array}{c}\text { Comparative } \\
\text { importance of } \\
\text { average value } \\
s_{j}\end{array}$ & $\begin{array}{c}\text { Coefficient } \\
k_{j}=s_{j}+1\end{array}$ & $\begin{array}{c}\text { Recalculated } \\
\text { weight } \\
w_{j}=\frac{w_{j-1}}{k_{j}}\end{array}$ & $\begin{array}{c}\text { Weight } \\
q_{j}=\frac{w_{j}}{\sum_{j=1}^{n} w_{j}}\end{array}$ \\
\hline $\mathrm{B}_{1}$ : Aversion to risk by project participants & - & 1 & 1 & 0.2067 \\
\hline $\mathrm{B}_{2}$ : Lack of efficient risk allocation mechanisms & 0.26 & 1.26 & 0.7936 & 0.1640 \\
\hline $\begin{array}{l}\mathrm{B}_{3}: \text { Lack of understanding of the benefits of optimal } \\
\text { allocation }\end{array}$ & 0.180 & 1.180 & 0.6725 & 0.1390 \\
\hline $\mathrm{B}_{4}:$ Competitive attitude & 0.161 & 1.161 & 0.5793 & 0.1197 \\
\hline $\mathrm{B}_{5}:$ Contract complexity & 0.138 & 1.138 & 0.5090 & 0.1052 \\
\hline $\mathrm{B}_{6}$ : Poor risk management communication & 0.104 & 1.104 & 0.4611 & 0.0953 \\
\hline $\mathrm{B}_{7}:$ Imbalance and abuse of power & 0.086 & 1.086 & 0.4245 & 0.0877 \\
\hline $\mathrm{B}_{8}$ : Lack of trust among project participants & 0.071 & 1.071 & 0.3964 & 0.0819 \\
\hline & & & $\sum_{j=1}^{n} w_{j}=4.8364$ & \\
\hline
\end{tabular}

water supply projects in order to ask each expert, based on their own experiences and implicit knowledge, to rank the importance of each criteria and barrier. As a result, the 10 criteria $\left(\mathrm{C}_{1}-\mathrm{C}_{10}\right.$, see Table 6$)$ and 8 barriers $\left(\mathrm{B}_{1}-\mathrm{B}_{10}\right.$, see Table 7) to optimal risk allocation of PPP water and sewerage projects were identified. These criteria and barriers are divided into two parts, with attention accorded to the impact of risk allocation. Criteria were beneficial factors $(+)$, and barriers were non-beneficial factors $(-)$; beneficial criteria are maximised, whereas non-beneficial criteria are minimised. The outcome of this step is used in the COPRAS method for the assessment of risks.

\subsection{Allocation of risk between parties using the SWARA-COPRAS method}

The primary objective of this study is to allocate types of risk in Malaysian water and sewerage PPP projects. The analysis of this section covered the perceptions of the public and private sector regarding allocation of PPP project risks. Risks are allocated by respondents to the party who can best handle them. This means respondents have selected the party actually taking the risk from one of the following three choices: public, private and shared by both the public and private sector.

Following the identification and evaluation of important risks, and after obtaining the weight of each risk allocation criteria and barrier, a COPRAS structure and questionnaire was designed and constructed by 10 experts to create mutual influence between each risk factor, criteria, barrier and alternative based on risk allocation. The 1-9 scale was used for this portion of the research.

Data were processed using Microsoft Excel to determine the initial decision-making matrix for risk allocation. Table 8 provides an example of the initial decision-making matrix and the weighted normalised decision-making matrix of risk allocation for uncertain tariff reviews $\left(\mathrm{R}_{42}\right)$ describing the compared risk allocation criteria and barriers.
The sums of the weighted normalised values for the beneficial criteria $\left(P_{i}\right)$ and the non-beneficial criteria (or barriers, $\left.R_{i}\right)$, the priority value $\left(Q_{i}\right)$, and the quantitative utility $\left(N_{i}\right)$ for uncertain tariff reviews $\left(\mathrm{R}_{42}\right)$ are shown in Table 9. According to Table 9, uncertain tariff reviews risk $\left(\mathrm{R}_{42}\right)$ must be allocated to the public sector.

The results of risk allocation for water and sewerage PPP projects in Malaysia are shown in Table 10. Referring to Table 10, the seven risks must be allocated to the private sector, namely ' $\mathrm{R}_{11}$ : High operational cost', ' $\mathrm{R}_{12}$ : Equipment defect and lack of maintenance,' ' $\mathrm{R}_{13}$ : Poor performance,' ' $R_{31}$ : Financial availability', ' $R_{32}$ : Unfavourable global private investment climate, ' $\mathrm{R}_{52}$ : Poor commitment from private party' and ' $\mathrm{R}_{62}$ : Delayed process'. This means the private sector has the ability to bear the least cost, control, foresee and assess, sustain, and assume and manage the occurrence and consequence (or loss) of these risks.

The output from the model reveals the six risks that must be allocated to the public sector, which included ' $\mathrm{R}_{21}$ : Political interference,' ' $\mathrm{R}_{22}$ : Termination of contract by government', ' $\mathrm{R}_{23}$ : Government's commitment risk', ' $\mathrm{R}_{42}$ : Uncertain tariff reviews' and ' $\mathrm{R}_{61}$ : Public opposition'. This means the public sector has the ability to control and manage these risks. For example, uncertain tariff and political interference are directly under the public's control, which therefore has a high capability to assume these risks in proportions of 0.922 and 0.954 , with the private sector having a low capability to control these risks. The government, through tariff resets and tariff indexation formulas, must extend a political commitment and charge economic tariffs. Therefore, it is the government's responsibility to prepare a well-functioning framework to encourage increases in water tariffs to help the private sector improve operations and services.

Table 10 shows that the 10 risk factors should be allocated between the public and private sector. These risks include ' $\mathrm{R}_{14}$ : Water theft,' ' $\mathrm{R}_{24}$ : Political corruption (government and 
Table 8. Sample of initial and weighted normalised decision-making matrix

\begin{tabular}{|c|c|c|c|c|c|c|c|}
\hline \multirow{2}{*}{} & \multirow{2}{*}{ Weight } & \multicolumn{3}{|c|}{ Initial matrix } & \multicolumn{3}{c|}{ Weighted normalized matrix } \\
\cline { 3 - 7 } & & Public & Shared & Private & Public & Shared & Private \\
\hline $\mathrm{C}_{1}$ & 0.1671 & 8 & 1 & 3 & 0.1114 & 0.0139 & 0.0418 \\
\hline $\mathrm{C}_{2}$ & 0.1381 & 9 & 2 & 2 & 0.0956 & 0.0212 & 0.0213 \\
\hline $\mathrm{C}_{3}$ & 0.1191 & 8 & 3 & 3 & 0.0681 & 0.0266 & 0.0255 \\
\hline $\mathrm{C}_{4}$ & 0.1048 & 7 & 2 & 2 & 0.0667 & 0.0191 & 0.0191 \\
\hline $\mathrm{C}_{5}$ & 0.0946 & 9 & 2 & 3 & 0.0608 & 0.0135 & 0.0203 \\
\hline $\mathrm{C}_{6}$ & 0.0868 & 8 & 1 & 2 & 0.0631 & 0.0079 & 0.0158 \\
\hline $\mathrm{C}_{7}$ & 0.0802 & 6 & 2 & 3 & 0.0438 & 0.0146 & 0.0219 \\
\hline $\mathrm{C}_{8}$ & 0.0743 & 7 & 2 & 3 & 0.0433 & 0.0124 & 0.0186 \\
\hline $\mathrm{C}_{9}$ & 0.0693 & 8 & 2 & 4 & 0.0396 & 0.0099 & 0.0198 \\
\hline $\mathrm{C}_{10}$ & 0.0652 & 8 & 2 & 4 & 0.0373 & 0.0093 & 0.0187 \\
\hline $\mathrm{B}_{1}$ & 0.2067 & 7 & 6 & 5 & 0.0804 & 0.0689 & 0.0574 \\
\hline $\mathrm{B}_{2}$ & 0.164 & 9 & 8 & 6 & 0.0642 & 0.0570 & 0.0428 \\
\hline $\mathrm{B}_{3}$ & 0.139 & 8 & 7 & 8 & 0.0485 & 0.0423 & 0.0484 \\
\hline $\mathrm{B}_{4}$ & 0.1197 & 8 & 6 & 7 & 0.0456 & 0.0342 & 0.0399 \\
\hline $\mathrm{B}_{5}$ & 0.1052 & 9 & 8 & 7 & 0.0395 & 0.0351 & 0.0307 \\
\hline $\mathrm{B}_{6}$ & 0.0953 & 8 & 7 & 6 & 0.0363 & 0.0318 & 0.0272 \\
\hline $\mathrm{B}_{7}$ & 0.0877 & 8 & 6 & 8 & 0.0319 & 0.0239 & 0.0319 \\
\hline $\mathrm{B}_{8}$ & 0.0819 & 7 & 5 & 7 & 0.0302 & 0.0216 & 0.0302 \\
\hline
\end{tabular}

Table 9. Risk allocation for uncertain tariff reviews risk

\begin{tabular}{|l|c|c|c|c|}
\hline & $P_{i}$ & $R_{i}$ & $Q_{i}=P_{i}+\frac{\sum_{i=1}^{n} R_{i}}{R_{i} \sum_{i=1}^{n} \frac{1}{R_{i}}}$ & $N_{i}=\frac{Q_{i}}{Q_{\max }} 100 \%$ \\
\hline Public & 0.6296 & 0.3763 & 0.9225 & 100 \\
\hline Shared & 0.1473 & 0.3148 & 0.4972 & 53.9 \\
\hline Private & 0.2225 & 0.3084 & 0.5799 & 62.84 \\
\hline
\end{tabular}

Table 10. Result of risk allocation in PPP water and sewerage projects in Malaysia

\begin{tabular}{|c|c|c|c|c|c|c|c|}
\hline \multirow{2}{*}{ Risk } & \multicolumn{3}{|c|}{$Q_{i}$} & \multicolumn{3}{|c|}{$N_{i}(\%)$} & \multirow{2}{*}{ Allocated } \\
\hline & Public & Shared & Private & Public & Shared & Private & \\
\hline $\begin{array}{l}\mathrm{R}_{11} \\
\mathrm{R}_{12} \\
\mathrm{R}_{13} \\
\mathrm{R}_{14}\end{array}$ & $\begin{array}{l}0.535 \\
0.521 \\
0.465 \\
0.345 \\
\end{array}$ & $\begin{array}{l}0.564 \\
0.443 \\
0.384 \\
0.943 \\
\end{array}$ & $\begin{array}{l}0.942 \\
0.896 \\
0.912 \\
0.446 \\
\end{array}$ & $\begin{array}{l}46.1 \\
58.1 \\
50.9 \\
36.5 \\
\end{array}$ & $\begin{array}{l}59.8 \\
49.4 \\
42.1 \\
100 \\
\end{array}$ & $\begin{array}{l}100 \\
100 \\
100 \\
57.9 \\
\end{array}$ & $\begin{array}{l}\text { Private } \\
\text { Private } \\
\text { Private } \\
\text { Shared }\end{array}$ \\
\hline $\begin{array}{l}\mathrm{R}_{21} \\
\mathrm{R}_{22} \\
\mathrm{R}_{23} \\
\mathrm{R}_{24} \\
\mathrm{R}_{25}\end{array}$ & $\begin{array}{l}0.954 \\
0.879 \\
0.768 \\
0.435 \\
0.763 \\
\end{array}$ & $\begin{array}{l}0.234 \\
0.123 \\
0.321 \\
0.675 \\
0.324 \\
\end{array}$ & $\begin{array}{l}0.324 \\
0.236 \\
0.223 \\
0.365 \\
0.365 \\
\end{array}$ & $\begin{array}{c}100 \\
100 \\
100 \\
64.5 \\
100 \\
\end{array}$ & $\begin{array}{c}24.5 \\
13.99 \\
41.8 \\
100 \\
42.4 \\
\end{array}$ & $\begin{array}{c}33.9 \\
26.8 \\
55.07 \\
54.07 \\
59.5 \\
\end{array}$ & $\begin{array}{l}\text { Public } \\
\text { Public } \\
\text { Public } \\
\text { Shared } \\
\text { Public }\end{array}$ \\
\hline $\begin{array}{l}\mathrm{R}_{31} \\
\mathrm{R}_{32} \\
\mathrm{R}_{33} \\
\end{array}$ & $\begin{array}{l}0.521 \\
0.342 \\
0.546 \\
\end{array}$ & $\begin{array}{l}0.453 \\
0.546 \\
0.923 \\
\end{array}$ & $\begin{array}{l}0.897 \\
0.786 \\
0.432 \\
\end{array}$ & $\begin{array}{c}58.08 \\
43.5 \\
59.15 \\
\end{array}$ & $\begin{array}{c}50.5 \\
69.4 \\
100 \\
\end{array}$ & $\begin{array}{l}100 \\
100 \\
61.5 \\
\end{array}$ & $\begin{array}{l}\text { Private } \\
\text { Private } \\
\text { Shared }\end{array}$ \\
\hline $\begin{array}{l}\mathrm{R}_{41} \\
\mathrm{R}_{42}\end{array}$ & $\begin{array}{l}0.432 \\
0.923 \\
\end{array}$ & $\begin{array}{l}0.896 \\
0.497 \\
\end{array}$ & $\begin{array}{l}0.426 \\
0.580 \\
\end{array}$ & $\begin{array}{c}48.21 \\
100 \\
\end{array}$ & $\begin{array}{l}100 \\
53.9 \\
\end{array}$ & $\begin{array}{c}58.7 \\
62.83 \\
\end{array}$ & $\begin{array}{l}\text { Shared } \\
\text { Public }\end{array}$ \\
\hline $\begin{array}{l}R_{51} \\
R_{52} \\
R_{53} \\
R_{54} \\
R_{55} \\
\end{array}$ & $\begin{array}{l}0.342 \\
0.543 \\
0.326 \\
0.442 \\
0.331 \\
\end{array}$ & $\begin{array}{l}0.845 \\
0.321 \\
0.876 \\
0.768 \\
0.896 \\
\end{array}$ & $\begin{array}{l}0.453 \\
0.863 \\
0.231 \\
0.274 \\
0.432 \\
\end{array}$ & $\begin{array}{c}40.4 \\
16.57 \\
37.21 \\
44.5 \\
25.7 \\
\end{array}$ & $\begin{array}{c}100 \\
37.19 \\
100 \\
100 \\
100 \\
\end{array}$ & $\begin{array}{c}53.6 \\
100 \\
26.36 \\
35.6 \\
48.2 \\
\end{array}$ & $\begin{array}{l}\text { Shared } \\
\text { Private } \\
\text { Shared } \\
\text { Shared } \\
\text { Shared }\end{array}$ \\
\hline $\begin{array}{l}\mathrm{R}_{61} \\
\mathrm{R}_{62} \\
\mathrm{R}_{63} \\
\end{array}$ & $\begin{array}{l}0.764 \\
0.265 \\
0.342 \\
\end{array}$ & $\begin{array}{l}0.342 \\
0.543 \\
0.845 \\
\end{array}$ & $\begin{array}{l}0.274 \\
0.861 \\
0.362 \\
\end{array}$ & $\begin{array}{c}100 \\
30.7 \\
40.47 \\
\end{array}$ & $\begin{array}{c}44.7 \\
63.06 \\
100 \\
\end{array}$ & $\begin{array}{c}35.8 \\
100 \\
51.1 \\
\end{array}$ & $\begin{array}{l}\text { Public } \\
\text { Private } \\
\text { Shared }\end{array}$ \\
\hline $\begin{array}{l}\mathrm{R}_{71} \\
\mathrm{R}_{72}\end{array}$ & $\begin{array}{l}0.425 \\
0.243\end{array}$ & $\begin{array}{l}0.768 \\
0.812\end{array}$ & $\begin{array}{l}0.312 \\
0.368\end{array}$ & $\begin{array}{c}55.5 \\
29.92\end{array}$ & $\begin{array}{l}100 \\
100\end{array}$ & $\begin{array}{l}40.69 \\
57.63\end{array}$ & $\begin{array}{l}\text { Shared } \\
\text { Shared }\end{array}$ \\
\hline
\end{tabular}


private sector),' ' $\mathrm{R}_{33}$ : Foreign exchange rate,' ' $\mathrm{R}_{41}$ : Delayed and non-payment of bills, ' $R_{51}$ : Strained relationships', ' $R_{53}$ : No risk allocation mechanism, ' $\mathrm{R}_{54}$ : Weak capacity of public and private partners', ' $\mathrm{R}_{55}$ : Inexperience in PPPs', ' $\mathrm{R}_{63}$ : Nopro-poor measures, ' $\mathrm{R}_{71}$ : Severe weather' and ' $\mathrm{R}_{72}$ : Natural disasters. This allocation for foreign exchange rates shows that this risk is not directly under the control of the public sector (government) or the private sector (investor), and no partner has a high capability to manage it. According to corruption risk, the private sector is more likely to unduly influence the procurement process through bribe offerings. The contracting authority, or the public sector, has a responsibility to ensure open, fair, transparent and competitive tendering without receiving bribes from the private sector or competing firms. The private sector should observe the rules of the game and gain the confidence of the marketplace, without making an offer. Water theft risk is allocated between the public and the private sector. This means the private sector should take steps to detect theft, discipline staff who facilitate theft and disconnect illegal connections. On the other hand, it is the public sector's responsibility to uphold the law and arrest and punish thieves, and the private sector or operator can claim compensation for losses. Non-payment of bills risk should be allocated between both sectors. The public sector should be committed to effecting strict collection policies and legal actions against defaulting customers, especially public institutions. The private sector also has the responsibility of identifying and disconnecting delinquent customers.

\section{Validation of model}

The model validation, through face-to-face interviews, was carried out in December 2015. Ten experts with direct hands-on experience in water and sewerage PPP projects in Malaysia were invited to evaluate: (1) the degree of comprehensiveness of risks included in the model; (2) the degree of objectivity of the model; (3) the degree of clarity of the model; (4) the overall reliability of the model; and (5) the degree of practicality of the model. The results of the validation experts are tabulated in Table 11. The average scores of all five criteria are well above 3.50 (Yeung, A. P. C. Chan, D. W. M. Chan, \& Li, 2007). Therefore, the result confirmed that the SWARA-COPRAS model is considered comprehensive, clear, objective, practical and reliable by the experts in the validation exercise.

\subsection{Balance allocation index}

Balance regarding allocation of risk is a crucial project success factor. The balance allocation index (BAI) was employed to verify the balanced risk allocation results between the proposed model and the previous study. It offers a realistic scale for assessing how any risk allocation model is actually balanced by reconciling the conflicting interests of contracting sectors (Khazaeni et al., 2012a). The BAI ratio can be measured by the contractor's share of risk allocation (private sector) against the employer's share of risk allocation (public sector).

$$
\mathrm{BAI}=\left(\frac{\text { private's share }}{\text { public's share }}\right) \text { if }
$$

$\left(\begin{array}{cc}\text { BAI }>1 & \text { private's share more than public } \\ \text { BAI }=1 & \text { balanced risk allocation between sectors } \\ \text { BAI }<1 & \text { public's share more than private }\end{array}\right)$.

The BAI ratio was measured from the findings of this study related to the risk allocation of PPP projects and is presented in Table 12 to confirm whether the balanced concept is well utilised inside the risk allocation models. In this study, private and public sector shares have a ratio of 12.359 and 12.451, respectively. From Table 12, it can be concluded that the allocation model presented by this study is more balanced and may provide a more stable model for the public and private sector, with a BAI ratio of 0.992 .

Table 12. BAI measurement in risk allocation frameworks

\begin{tabular}{|l|c|}
\hline \multicolumn{1}{|c|}{ Share } & Ratio \\
\hline Private's share & 12.359 \\
\hline Public's share & 12.451 \\
\hline & BAI $=0.992$ \\
\hline
\end{tabular}

\subsection{Sensitivity analysis}

A sensitivity analysis is conducted to determine changes in the particular ranking of alternatives, as well as changes in particular weights from the main factors proposed by the respondents employed in this study. To test the stability of our decision, this study performed a sensitivity analysis to test the robustness of the decision with respect to changes in the weighting of the criteria and barriers. To determine sensitivity ranges and to change

Table 11. Results of validation exercise for SWARA-COPRAS risk allocation model

\begin{tabular}{|c|c|c|c|c|c|c|c|c|c|c|c|}
\hline Validation criteria & \multicolumn{10}{|c|}{ Scores rated by experts } & \multirow{2}{*}{$\begin{array}{c}\begin{array}{c}\text { Average } \\
\text { scores }\end{array} \\
4.3\end{array}$} \\
\hline $\begin{array}{l}\text { 1. Degree of comprehensiveness of } \\
\text { risks included in the model }\end{array}$ & 4 & 5 & 3 & 4 & 5 & 4 & 5 & 4 & 5 & 4 & \\
\hline 2. Degree of objectivity of the model & 5 & 4 & 5 & 4 & 3 & 4 & 5 & 5 & 4 & 4 & 4.3 \\
\hline 3. Degree of clarity of the model & 4 & 4 & 5 & 3 & 4 & 4 & 5 & 3 & 3 & 5 & 4 \\
\hline 4. Overall reliability of the model & 4 & 5 & 3 & 4 & 4 & 4 & 4 & 5 & 5 & 5 & 4.7 \\
\hline 5. Degree of practicality of the model & 3 & 3 & 4 & 5 & 5 & 4 & 4 & 4 & 4 & 4 & 4 \\
\hline
\end{tabular}


Table 13. Values to sensitivity analysis for uncertain tariff reviews risk based on criteria

\begin{tabular}{|c|c|c|c|c|}
\hline \multirow{2}{*}{$\begin{array}{c}\text { Input } \\
\text { value }\end{array}$} & \multirow{2}{*}{$\begin{array}{c}\text { Priority of } \\
\text { criteria }\end{array}$} & \multicolumn{3}{|c|}{ Weight of each part } \\
\cline { 3 - 5 } & & Private & Public & Shared \\
\hline- & 0.01 & 0.25 & 0.18 & 0.57 \\
\hline 0.05 & 0.06 & 0.25 & 0.18 & 0.57 \\
\hline 0.11 & 0.11 & 0.25 & 0.18 & 0.58 \\
\hline 0.16 & 0.17 & 0.24 & 0.18 & 0.58 \\
\hline 0.21 & 0.22 & 0.24 & 0.18 & 0.58 \\
\hline 0.26 & 0.27 & 0.24 & 0.18 & 0.59 \\
\hline 0.32 & 0.32 & 0.24 & 0.17 & 0.59 \\
\hline 0.37 & 0.37 & 0.23 & 0.17 & 0.59 \\
\hline 0.42 & 0.43 & 0.23 & 0.17 & 0.60 \\
\hline 0.47 & 0.48 & 0.23 & 0.17 & 0.60 \\
\hline 0.50 & 0.53 & 0.22 & 0.17 & 0.60 \\
\hline 0.58 & 0.58 & 0.22 & 0.17 & 0.61 \\
\hline 0.63 & 0.64 & 0.22 & 0.17 & 0.61 \\
\hline 0.68 & 0.69 & 0.21 & 0.17 & 0.62 \\
\hline 0.74 & 0.74 & 0.21 & 0.17 & 0.62 \\
\hline 0.79 & 0.79 & 0.21 & 0.17 & 0.62 \\
\hline 0.84 & 0.84 & 0.20 & 0.17 & 0.63 \\
\hline 0.89 & 0.90 & 0.20 & 0.17 & 0.63 \\
\hline 0.95 & 0.95 & 0.20 & 0.17 & 0.63 \\
\hline 1 & 1 & 0.19 & 0.17 & 0.64 \\
\hline
\end{tabular}

the weights of main factors, we adopted two processes. First, the major impacting factors and subfactors were determined. The weights of major impacting factors and subfactors vary from (0.05 to 1$)$. Various values were investigated to examine the impact of barrier factors and criteria on the final weights; this section discusses the three alternatives; similar outcomes were found for related sub-elements. A sample sensitivity analysis of the final decision of 'uncertain tariff reviews' risk is shown in Table 13. The alternative rating does not change if the relative significance is increased from 0.5 and decreased from 0.5. This reveals that ranking of alternatives does not change if managerial preferences and expert judgments increase or decrease. Therefore, at this particular level, the solution is extremely robust, with little change in ultimate selection. Stakeholders in PPP projects can be confident that sharing between partners for each risk is a better choice. The sample of the sensitivity analysis of the final decision of 'uncertain tariff reviews' risk is shown in Figure 3. Therefore, the proposed model can help stakeholders in sewerage and water supply PPP projects to determine the best strategy for sharing risk.

\section{Conclusions}

Appropriate risk allocation between the public and private sector is a vital factor in achieving success in the implementation of public-private partnership (PPP) projects.

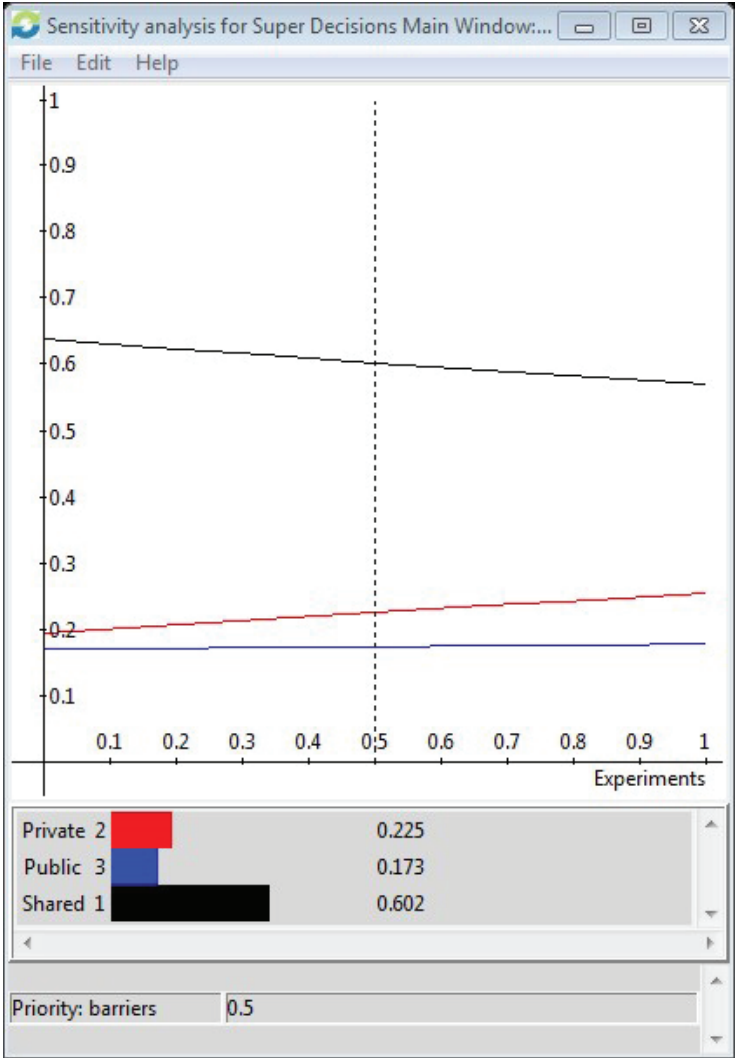

Figure 3. Sensitivity analysis for uncertain tariff reviews risk based on barriers

Risk allocation may fail to be achieved due to the lack of a joint risk management mechanism. In addition, inappropriate risk allocation can negatively affect the project management triangle of time, cost, and quality, in realising the success of PPP projects. Remarkably, the process of risk allocation should be recognised based on the abilities of both parties in PPP projects. In fact, both responsibility and accountability play significant roles in PPP projects. The proper allocation of risk in PPP projects is a flexible and complex procedure, which often causes conflict between the partners. Equitable risk allocation depends on many factors, such as the ability to manage risk and the attitude of stakeholders towards risk. This paper has explained risk allocation in PPP water and sewerage projects in Malaysia based on the SWARA-COPRAS method, which can be modelled to reflect risk allocation criteria and barriers. In this research, the criteria were considered positive factors and the barriers were considered negative factors based on the COPRAS method. The COPRAS technique is adopted for analysis and decision-making because it deals well with the ambiguity in the barriers and criteria for risk allocation and accurately accounts for the expert knowledge that characterises risk-allocation decision-making. In this study, the risk matrix was used to identify significant risks. Based on the questionnaire survey and the risk assessment matrix, the 24 important risks inherent in Malaysian water and sewerage PPP projects were identified, in addition to five significant risk 
factors in PPP water and sewerage in Malaysia, including 'Political interference $\left(\mathrm{R}_{21}\right)$ ', 'Political corruption risk $\left(\mathrm{R}_{24}\right)$ ', 'Water theft $\left(\mathrm{R}_{14}\right)$ ', 'Foreign exchange' and 'Nonpayment bills $\left(\mathrm{R}_{41}\right)$.' The 10 criteria and eight barriers to risk allocation were identified through a literature review, and the weight of each criterion and barrier was obtained by analysis using the SWARA method. Finally, the results obtained from the COPRAS method included a total of 24 significant risks, with six risks allocated to the public sector, seven risks allocated to the private sector, and 11 risks shared between the public and private sector.

It is vital for the private and public sector to understand the various risks related to water supply and sewerage PPPs through the entire life cycle of infrastructure projects, as well as the significance of risks and the best way to allocate them to ensure long-term achievement of partnerships. The identification, classification, evaluation and investigation of problems of this particular current practice of allocation of risk, and the evaluation of positive and negative factors to optimal risk allocation in water supply and sewerage PPP projects, represent an authentic contribution to the body of knowledge and to the PPP projects. The findings from this research may help the public and private sector to develop a framework that can be used for bidding to predict and respond to risks in water and sewerage projects, therefore saving time in arbitration and contract transactions. This study should help project stakeholders in terms of better risk management, time savings, reduced overall cost, and the enhancement of the general quality of PPP water and sewerage projects. The model provides an innovative and helpful instrument to PPP industry experts and providers through the introduction of a realistic mechanism regarding the development of a better decision support model for optimal risk allocation. Furthermore, the results would certainly help to impact public policy improvement towards PPP and the way in which various sectors can carry out PPP contracts with due respect for their risk perceptions.

\section{References}

Abdulai, A.-G. (2009). Political will in combating corruption in developing and transition economies: a comparative study of Singapore, Hong Kong and Ghana. Journal of Financial Crime, 16(4), 387-417. https://doi.org/10.1108/13590790910993753

Aghdaie, M. H., Zolfani, S. H., \& Zavadskas, E. K. (2013). Decision making in machine tool selection: an integrated approach with SWARA and COPRAS-G methods. Inzinerine Ekonomika - Engineering Economics, 24(1), 5-17. https://doi.org/10.5755/j01.ee.24.1.2822

Alireza, V., Mohammadreza, Y., Zin, R. M., Yahaya, N., \& Noor, N. M. (2013). An enhanced multi-objective optimization approach for risk allocation in public-private partnership projects: a case study of Malaysia. Canadian Journal of Civil Engineering, 41(2), 164177. https://doi.org/10.1139/cjce-2013-0342

Ameyaw, E. E., \& Chan, A. P. (2015). Evaluation and ranking of risk factors in public - private partnership water supply projects in developing countries using fuzzy synthetic evaluation approach. Expert Systems with Applications, 42(12), 5102-5116. https://doi.org/10.1016/j.eswa.2015.02.041
Ameyaw, E. E., \& Chan, A. P. (2016). A fuzzy approach for the allocation of risks in public-private partnership water-infrastructure projects in developing countries. Journal of Infrastructure Systems, 22(3).

https://doi.org/10.1061/(ASCE)IS.1943-555X.0000297

Ameyaw, E. E., \& Chan, A. P. C. (2013). Identifying publicprivate partnership (PPP) risks in managing water supply projects in Ghana. Journal of Facilities Management, 11(2), 152-182. https://doi.org/10.1108/14725961311314651

Bhatnagar, R., Kim, J., \& Many, J. E. (2014). Candidate surveys on program evaluation: examining instrument reliability, validity and program effectiveness. American Journal of Educational Research, 2(8), 683-690.

https://doi.org/10.12691/education-2-8-18

Bing, L., Akintoye, A., Edwards, P. J., \& Hardcastle, C. (2005). The allocation of risk in PPP/PFI construction projects in the UK. International Journal of Project Management, 23(1), 2535. https://doi.org/10.1016/j.ijproman.2004.04.006

Carbonara, N., Costantino, N., Gunnigan, L., \& Pellegrino, R. (2015). Risk management in motorway PPP projects: empirical-based guidelines. Transport Reviews, 35(2), 162-182. https://doi.org/10.1080/01441647.2015.1012696

Chan, A. P., Lam, P. T., Wen, Y., Ameyaw, E. E., Wang, S., \& Ke, Y. (2015). Cross-sectional analysis of critical risk factors for PPP water projects in China. Journal of Infrastructure Systems, 21(1). https://doi.org/10.1061/(ASCE)IS.1943-555X.0000214

Chang, C.-Y. (2014). Principal-agent model of risk allocation in construction contracts and its critique. Journal of Construction Engineering and Management, 140(1). https://doi.org/10.1061/(ASCE)CO.1943-7862.0000779

Choi, J., Chung, J., \& Lee, D.-J. (2010). Risk perception analysis: participation in China's water PPP market. International Journal of Project Management, 28(6), 580-592.

https://doi.org/10.1016/j.ijproman.2009.10.010

Department of Occupational Safety and Health. (2008). Guidelines for hazard identification, risk assessment, and risk control. Department of Occupational Safety and Health, Ministry of Human Resources, Malaysia. Retrieved from http://www. utar.edu.my/osh/file/58.\%20DOSH\%20-HIRARC\%20Guidelines\%20-\%202008.pdf

Economic Planning Unit, Prime Minister's Department. (2010). Building an environment that enhances quality of life (Chapter 6). In Tenth Malaysia Plan, 2011-2015. Retrieved from http://onlineapps.epu.gov.my/rmke10/img/pdf/en/chapt6.pdf

El-Sayegh, S. M. (2008). Risk assessment and allocation in the UAE construction industry. International Journal of Project Management, 26(4), 431-438.

https://doi.org/10.1016/j.ijproman.2007.07.004

FAO/ESCAP. (2001). From vision to action: a synthesis of experiences in Southeast Asia. The FAO-ESCAP Pilot project on national water visions (L. H. Ti \& T. Facon, Eds.). Food and Agriculture Organization of the United Nations, Economic and Social Commission for Asia and the Pacific, Bangkok. Retrieved from http://www.fao.org/docrep/004/AB776E/ ab776e 02.htm\#bm2

Grasso, P., \& Soldo, L. (2017). Risk analysis-driven design in tunnelling: the state-of-the-art, learnt from past experiences, and horizon for future development. Innovative Infrastructure Solutions, 2, 49. https://doi.org/10.1007/s41062-017-0087-2

Hall, D., \& Lobina, E. (2007). International actors and multinational water company strategies in Europe, 1990-2003. Utilities Policy, 15(2), 64-77.

https://doi.org/10.1016/j.jup.2007.02.005 
Hwang, B.-G., Zhao, X., \& Gay, M. J. S. (2013). Public private partnership projects in Singapore: factors, critical risks and preferred risk allocation from the perspective of contractors. International Journal of Project Management, 31(3), 424-433. https://doi.org/10.1016/j.ijproman.2012.08.003

Hwang, B.-G., Zhao, X., \& Yu, G. S. (2016). Risk identification and allocation in underground rail construction joint ventures: contractors' perspective. Journal of Civil Engineering and Management, 22(6), 758-767.

https://doi.org/10.3846/13923730.2014.914095

Iqbal, S., Choudhry, R. M., Holschemacher, K., Ali, A., \& Tamošaitienè, J. (2015). Risk management in construction projects. Technological and Economic Development of Economy, 21(1), 65-78.

https://doi.org/10.3846/20294913.2014.994582

Jae-Seung, L., \& Yea-Sang, K. (2017). Analysis of cost-increasing risk factors in modular construction in Korea Using FMEA. KSCE Journal of Civil Engineering, 21(6), 1999-2010. https://doi.org/10.1007/s12205-016-0194-1

Jin, X. H., \& Doloi, H. (2008). Interpreting risk allocation mechanism in public-private partnership projects: an empirical study in a transaction cost economics perspective. Construction Management and Economics, 26(7), 707-721. https://doi.org/10.1080/01446190801998682

Jin, X.-H., \& Zhang, G. (2011). Modelling optimal risk allocation in PPP projects using artificial neural networks. International Journal of Project Management, 29(5), 591-603. https://doi.org/10.1016/j.ijproman.2010.07.011

Kaklauskas, A., Zavadskas, E. K., Raslanas, S., Ginevicius, R., Komka, A., \& Malinauskas, P. (2006). Selection of low-e windows in retrofit of public buildings by applying multiple criteria method COPRAS: a Lithuanian case. Energy and Buildings, 38(5), 454-462. https://doi.org/10.1016/j.enbuild.2005.08.005

Karabašević, D., Stanujkić, D., Urošević, S., \& Maksimović, M. (2016). An approach to personnel selection based on SWARA and WASPAS methods. Bizinfo (Blace), 7(1), 1-11.

https://doi.org/10.5937/bizinfo1601001K

Kauffmann, C., \& Pérard, E. (2007). Stocktaking of the water and sanitation sector and private sector involvement in selected African countries. Background note for the regional roundtable on Strengthening Investment Climate Assessment and Reform in NEPAD Countries. Lusaka, Zambia. Retrieved from http://www.oecd.org/dataoecd/17/8/39679099.pdf

Ke, Y., Wang, S. Q., \& Chan, A. P. C. (2013). Risk misallocation in public-private partnership projects in China. International Public Management Journal, 16(3), 438-460. https://doi.org/10.1080/10967494.2013.825508

Keršuliene, V., Zavadskas, E. K., \& Turskis, Z. (2010). Selection of rational dispute resolution method by applying new stepwise weight assessment ratio analysis (SWARA). Journal of Business Economics and Management, 11(2), 243-258. https://doi.org/10.3846/jbem.2010.12

Khazaeni, G., Khanzadi, M., \& Afshar, A. (2012a). Fuzzy adaptive decision making model for selection balanced risk allocation. International Journal of Project Management, 30(4), 511-522. ttps://doi.org/10.1016/j.ijproman.2011.10.003

Khazaeni, G., Khanzadi, M., \& Afshar, A. (2012b). Optimum risk allocation model for construction contracts: fuzzy TOPSIS approach. Canadian Journal of Civil Engineering, 39(7), 789-800. https://doi.org/10.1139/12012-038

Kundakcı, N., \& Işık, A. (2016). Integration of MACBETH and COPRAS methods to select air compressor for a textile company. Decision Science Letters, 5(3), 381-394.

https://doi.org/10.5267/j.dsl.2016.2.003
Lam, K., Wang, D., Lee, P. T., \& Tsang, Y. (2007). Modelling risk allocation decision in construction contracts. International Journal of Project Management, 25(5), 485-493. https://doi.org/10.1016/j.ijproman.2006.11.005

Loosemore, M., \& McCarthy, C. (2008). Perceptions of contractual risk allocation in construction supply chains. Journal of Professional Issues in Engineering Education and Practice, 134(1). https://doi.org/10.1061/(ASCE)1052-3928(2008)134:1(95)

Marques, R. C., \& Berg, S. (2011). Risks, contracts, and publicsector participation in infrastructure. Journal of Construction in Engineering and Management, 137(11).

https://doi.org/10.1061/(ASCE)CO.1943-7862.0000347

Mulliner, E., Malys, N., \& Maliene, V. (2016). Comparative analysis of MCDM methods for the assessment of sustainable housing affordability. Omega, 59, 146-156.

https://doi.org/10.1016/j.omega.2015.05.013

Organ, A., \& Yalçın, E. (2016). Performance evaluation of research assistants by COPRAS method. European Scientific Journal, 12(10), 102-109.

Osei-Kyei, R., \& Chan, A. P. (2015). Developing transport infrastructure in Sub-Saharan Africa through public-private partnerships: policy practice and implications. Transport Reviews, 36(2), 170-186.

https://doi.org/10.1080/01441647.2015.1077288

Tan, J. (2012). The pitfalls of water privatization: failure and reform in Malaysia. World Development, 40(12), 2552-2563. https://doi.org/10.1016/j.worlddev.2012.05.012

Valipour, A., Mohammadi, F., Yahaya, N., Sarvari, H., \& Noor, N. M. (2014). Identification and evaluation of risk allocation criteria and barriers: a Malaysian public private partnership project case study. Journal of Applied Sciences, 14(18), 2023-2031. https://doi.org/10.3923/jas.2014.2023.2031

Valipour, A., Yahaya, N., Md Noor, N., Kildienè, S., Sarvari, H., \& Mardani, A. (2015). A fuzzy analytic network process method for risk prioritization in freeway PPP projects: an Iranian case study. Journal of Civil Engineering and Management, 21(7), 933-947. https://doi.org/10.3846/13923730.2015.1051104

Wibowo, A., \& Mohamed, S. (2010). Risk criticality and allocation in privatised water supply projects in Indonesia. International Journal of Project Management, 28(5), 504-513. https://doi.org/10.1016/j.ijproman.2009.08.003

World Bank. (2016). Private participation in infrastructure database. The World Bank Group. Retrieved from http://ppi. worldbank.org/snapshots/country/malaysia

Xu, Y., Chan, A. P., \& Yeung, J. F. (2010). Developing a fuzzy risk allocation model for PPP projects in China. Journal of Construction Engineering and Management, 136(8), 894-903. https://doi.org/10.1061/(ASCE)CO.1943-7862.0000189

Yang, T., Long, R., Cui, X., Zhu, D., \& Chen, H. (2017). Application of the public-private partnership model to urban sewage treatment. Journal of Cleaner Production, 142(Part 2), 10651074. https://doi.org/10.1016/j.jclepro.2016.04.152

Yeung, J. F. Y., Chan, A. P. C., Chan, D. W. M., \& Li, L. K. (2007). Development of a partnering performance index (PPI) for construction projects in Hong Kong: a Delphi study. Construction Management and Economics, 25(12), 1219-1237. https://doi.org/10.1080/01446190701598673

Zavadskas, E. K., \& Kaklauskas, A. (1996). Determination of an efficient contractor by using the new method of multicriteria assessment. In D. A. Langford \& A. Retik (Eds.), International symposium for "The Organization and Management of Construction", Shaping Theory and Practice: Vol. 2. Managing the construction project and managing risk (pp. 94-104). CIB W65. London: E and FN SPON. 
Zavadskas, E. K., Kaklauskas, A., Peldschus, F., \& Turskis, Z. (2007). Multi-attribute assessment of road design solutions by using the COPRAS method. Baltic Journal of Road \& Bridge Engineering, 2(4), 195-203.

Zavadskas, E. K., Kaklauskas, A., Turskis, Z., \& Tamošaitiene, J. (2008). Selection of the effective dwelling house walls by applying attributes values determined at intervals. Journal of Civil Engineering and Management, 14(2), 85-93. https://doi.org/10.3846/1392-3730.2008.14.3

Zavadskas, E. K., Turskis, Z., \& Tamosaitiene, J. (2010). Risk assessment of construction projects, Journal of Civil Engineering and Management, 16(1), 33-46. https://doi.org/10.3846/jcem.2010.03

Zeng, S., Wan, T., Tam, C., \& Liu, D. (2007). Identifying risk factors of BOT for water supply projects. In Proceedings of the
Institution of Civil Engineers, Water Management 161(WM2) (pp. 73-81).

Zhang, L., Ding, L., Wu, X., \& Skibniewski, M. J. (2017). An improved Dempster-Shafer approach to construction safety risk perception. Knowledge-Based Systems, 132, 30-46. https://doi.org/10.1016/j.knosys.2017.06.014

Zolfani, S. H., \& Bahrami, M. (2014). Investment prioritizing in high tech industries based on SWARA-COPRAS approach, Technological and Economic Development of Economy, 20(3), 534-553. https://doi.org/10.3846/20294913.2014.881435

Zolfani, S. H., \& Saparauskas, J. (2013). New application of SWARA method in prioritizing sustainability assessment indicators of energy system. Inzinerine Ekonomika-Engineering Economics, 24(5), 408-414.

https://doi.org/10.5755/j01.ee.24.5.4526 